\title{
OBITUARY
}

\section{SIR GERARD CLAUSON}

Sir Gerard Clauson, who died on 1 May 1974, had at the time of his death been a Fellow of this Society for 62 years, a period equalled in this century only by Sir Archibald Creswell. Born in 1891, he joined the Society in 1912 as an undergraduate at Corpus Christi College, Oxford; he was President for the triennium 1958-61; and in 1973 he was awarded the special gold medal commemorating the Society's sesquicentenary.

His exceptional gift for languages won him a series of distinctions in his early years. His first publication, under the name "G. L. M. Clauson, K.S., of Eton College" and dated 6 November 1906, was a short Pali text. He read Greats at Oxford, where he was Boden Sanskrit Scholar in 1911, Hall-Houghton Syriac Prizeman in 1913, and James Mew Arabic Scholar in 1920. But as he himself put it, "the First War and the need to earn a living diverted my interest into other channels"- - a distinguished career in the Colonial Office, where he was Assistant Under-Secretary from 1940 until his retirement in 1951. Throughout his Civil Service career, however, he kept up his interest in philology and archaeology, publishing the occasional article and acquiring new languages, among them Russian and Chinese, while he started his first notebook on Japanese the day after the attack on Pearl Harbor. The list of his publications shows the breadth of his philological studies throughout his life; it shows also how the number of his published papers increased from the 1950's, when retirement afforded him more leisure. In these later years his interests concentrated on the study of Turkish (for which, he wrote, he "first acquired an affection at the age of fifteen") and more particularly on the question of the validity of the Altaic theory, the doctrine that the Turkish, Mongolian, and Tungus languages are genetically related. Hence, although this Society remained as it were his academic base, he found a second and most congenial academic milieu in the annual meetings of the Permanent International Altaistic Conference.

The writer of The Times obituary remarked that "he was never a "yes" man, either in official or private life". Nor was he in the academic field, where the starting-point for many of his articles and for his sometimes pungent reviews was an aversion for expressing admiration of the Emperor's new clothes unless he was sure that he could see them. To take a minor illustration: few things gave him greater pleasure than the detection of a ghost-word, particularly when it appeared to be authoritatively attested; while on a broader front it was this scepticism which led him not merely to abstain from accepting the Altaic theory but to seek to refute it.

The year of his birth suggests that he ought to have been rather old-fashioned, and in two respects perhaps he was: he held firmly to the conviction, now outmoded but not yet entirely discredited, that the study of the classics is the foundation of a liberal education; and he exemplified in his career the dying tradition of the amateur scholar or, in other terms, of the scholarly public servant. Otherwise, however, no octogenarian ever belied his years more convincingly. Right up to his death he retained a positively juvenile zest and an iconoclastic wit that made him a lively and stimulating companion. But the characteristic that his friends would particularly wish to record was his great kindliness and patience. He gave generously of his time and of his expertise to the affairs of this Society, whose interests he always sought to promote; while at the personal level any postcard addressed to him with a lexical query would receive, usually by return of post, a detailed and authoritative answer in his distinctive and near-calligraphic hand, a hand so neat and clear that his monumental Etymological dictionary, the culmination of a lifetime's study, was set up in type direct from his manuscript. 
1. "A new Kammavācã", JPTS, 1906-7, 1-7.

2. "Catalogue of the Stein collection of Sanskrit MSS. from Kashmir", JRAS, 1912, $587-627$.

3. (with F. W. Thomas) "A Chinese Buddhist text in Tibetan writing", JRAS, 1926, 508-26.

4. (with F. W. Thomas) "A second Chinese Buddhist text in Tibetan characters", JRAS, 1927, 281-306.

5. “A hitherto unknown Turkish manuscript in 'Uighur' characters”, JRAS, 1928, 99-130.

6. (with S. Yoshitake) "On the phonetic value of the Tibetan characters 3 and 2 and the equivalent characters in the hPhags.pa alphabet", JRAS, 1929, 843-62.

7. "The geographical names in the Staël-Holstein Scroll", JRAS, 1931, 297-309.

8. "Turkish ghost words", JRAS, 1955, 124-38.

9. "A note on Qapqan", JRAS, 1956, 73-7.

10. "The case against the Altaic theory", $C A J, \mathrm{II}, 3,1956,181-7$.

11. "A propos du manuscrit Pelliot tibétain 1283", JA, 1957, 11-24.

12. "The Turkish Y and related sounds", Studia Altaica: Festschrift N. Poppe, 1957, 33-45.

13. "The Ongin inscription", JRAS, 1957, 177-92.

14. "Türkçe sözler üzerinde araştırmalar", Jean Deny Armağant, Ankara, 1958, 67-70.

15. "The Turkish numerals", JRAS, 1959, 19-31.

16. "The hP'ags-pa alphabet", BSOAS, XXII, 2, 1959, 300-23.

17. "The earliest Turkish loan words in Mongolian", CAJ, IV, 3, 1959, 174-87.

18. "The Turkish elements in 14th century Mongolian", CAJ, V, 4, 1960, 301-16.

19. Sanglaxx: a Persian guide to the Turkish language, by Muhammad Mahdi Xän. Facsimile text with an introduction and indices, E. J. W. Gibb Memorial, n.s. XX, 1960.

20. "Turk, Mongol, Tungus", Asia Major, n.s. VIII, 1, 1960, 105-23.

21. "Ak Beshim-Suyab", JRAS, 1961, 1-13.

22. "The initial labial sounds in the Turkish languages", BSOAS, XXIV, 2, 1961, 298-306.

23. "Notes on the 'Irk Bitig" ", Ural-Altaische Jahrbücher, XXXIII, 3-4, 1961, 218-25.

24. Turkish and Mongolian studies, Royal Asiatic Society, Prize Publication Fund Vol. XX, 1962.

25. "The concept of 'strength' in Turkish", Németh Armağanı, Ankara, 1962, 93-101.

26. "The Muhabbat-nāma of Xwārazmi", CAJ, VII, 4, 1962, 241-55.

27. "The diffusion of writing in the Altaic world", Aspects of Altaic civilization, ed. D. Sinor, Bloomington and The Hague, 1963, 139-44.

28. "The name Uyğur", JRAS, 1963, 140-9 (Russian tr. in Issledovaniya po uygurskomu yazuiku, Alma-Ata, 1965, 209-20).

29. "Turks and wolves", Studia Orientalia, XXVIII, 2, 1964, 22 pp.

30. "A postscript to Professor Sinor's 'Observations on a new comparative Altaic phonology'", BSOAS, XXVII, 1, 1964, 154-6.

31. "Early Turkish astronomical terms", Ural-Altaische Jahrbücher, XXXV, 1964, 350-68.

32. "The future of Tangut (Hsi Hsia) studies", Asia Major, n.s. XI, 1, 1964, 54-77.

33. (with C. E. Bosworth) "al-Xwärazmi on the peoples of Central Asia", JRAS, 1965, 2-12.

34. "Turkish and Mongolian horses and use of horses, an etymological study", $C A J, \mathrm{X}$, $3-4,1965,161-6$.

35. "Three Mongolian notes", Collectanea Mongolica: Festschrift für Professor Dr. Rintchen, (Asiatische Forschungen, XVII), Wiesbaden, 1966, 29-34.

36. "Three notes on early Turkish", Türk Dili Araştırmaları Yıllı̈̆ı, Belleten 1966, 1967, 1-18 (and Turkish tr., 19-37).

37. "Some old Turkish words connected with hunting", Die Jagd bei den altaischen Völkern, (Asiatische Forschungen, XXVI), Wiesbaden, 1968, 9-17.

38. (with J. Chadwick) “The Indus script deciphered?", Antiquity, XLIII, 1969, 200-7. 
39. "A lexicostatistical appraisal of the Altaic theory", CAJ, XIII, 1, 1969, 1-23 (Russian tr. in Voprosui Yazuikoznaniya, V, 1969, 22-41).

40. "Tatar poets of the First Great War", JRAS, 1969, 151-60.

41. "The origin of the Turkish 'runic' alphabet", Acta Orientalia, XXXII, 1970, 51-76.

42. (with E. Tryjarski) "The inscription at Ikhe Khushotu", Rocznik Orientalistyczny, XXXIV, 1, 1971, 7-33.

43. “Armeno-Qipcaq", Rocznik Orientalistyczny, XXXIV, 2, 1971, 7-13.

44. "A late Uyğur family archive", Iran and Islam, ed. C. E. Bosworth, Edinburgh, 1971, $167-96$.

45. "Some notes on the inscription of Toñuqu", Studia Turcica, ed. L. Ligeti, Budapest, $1971,125-32$.

46. An etymological dictionary of pre-thirteenth-century Turkish, Oxford, 1972.

47. "Philology and archaeology", Antiquity, XLVII, 1973, 37-42.

48. "The Turkish-Khotanese vocabulary re-edited", Islâm Tetkikleri Enstitüsü Dergisi, V, $1973,37-45$.

49. "Nostratic", JRAS, 1973, 46-55.

50. "Turkish philology in Hungary", Asia Major, XVIII, 2, 1973, 209-19.

51. "Two Uygur administrative orders", Ural-Altaische Jahrbücher, XLV, 1973, 213-22.

52. "The foreign elements in early Turkish", in Researches in Altaic languages, ed. L. Ligeti, Budapest, 1975, 43-9.

In the Foreword to his Turkish and Mongolian studies (No. 24), Clauson speaks of his first plan "to compile a new and better "Radloff", i.e. a historical dictionary of all the Turkish languages from the earliest times to the present day. Realizing after six years' work, when he had completed the words beginning with vowels and about half of those beginning with $c-/ c$-, that he might never manage to complete it, he began again "on a much more modest scale" to compile the Etymological dictionary (No. 46), with its terminus in the thirteenth century, which was published two years before his death. Clauson was conscious of the deficiencies of his "new Radloff"; yet it would have been too cavalier to destroy the product of so much meticulous labour. Through the kindness of Lady Clauson, therefore, the draft-3,900 closely-written pages in 15 loose-leaf books-has been lodged in the Society's library. Sir Gerard would not object to our borrowing in this connexion the words of Sir James Redhouse, that other distinguished lexicographer of Turkish closely connected with the Royal Asiatic Society, who deposited his uncompleted Thesaurus in the British Museum "partly as an inducement to do better, and partly as a warning against attempting too much".

As a result of the lively correspondence which he maintained with Turcologists and other scholars in all parts of the world, Sir Gerard had accumulated a very extensive collection of offprints of articles and reviews, which is particularly rich in the publications, sometimes difficult of access, of the USSR. These too Lady Clauson has generously presented to the Society, where they are available to readers, in a series of box-files, as "the Clauson offprints".

V. L. Ménage. 